\title{
Sampling and evaluation of white spot syndrome virus in commercially important Atlantic penaeid shrimp stocks
}

\author{
Robert W. Chapman*, Craig L. Browdy, Suzanne Savin, Sarah Prior, Elizabeth Wenner \\ South Carolina Department of Natural Resources, Marine Resources Research Institute, 217 Ft. Johnson Road, \\ Charleston, South Carolina 29412, USA
}

\begin{abstract}
In 1997, white spot syndrome virus (WSSV) was discovered in shrimp culture facilities in South Carolina, USA. This disease was known to cause devastating mortalities in cultured populations in Southeast Asia and prompted concern for the health of wild populations in the USA. Our study surveyed wild shrimp populations for the presence of WSSV by utilizing molecular diagnostics and bioassay techniques. A total of 1150 individuals (586 Litopenaeus setiferus, 477 Farfantepenaeus aztecus and $87 \mathrm{~F}$. dourarum) were examined for the presence of WSSV DNA by PCR. A total of 32 individuals tested positive and were used in a bioassay to examine the transmission of disease to healthy individuals of the culture species $L$. vannamei. DNA sequencing of PCR products from a positive individual confirmed that the positive individuals carried WSSV DNA. Significant mortalities were seen in test shrimp injected with tissue extracts from heavily infected wild shrimp. These data confirm the existence of WSSV in wild shrimp stocks along the Atlantic Coast and that the virus can cause mortalities in cultured stocks.
\end{abstract}

KEY WORDS: Penaeid $\cdot$ Shrimp $\cdot$ White spot virus $\cdot$ Disease $\cdot$ Native species $\cdot$ PCR

\section{INTRODUCTION}

Outbreaks of shrimp virus are a major problem associated with the development and expansion of the shrimp farming industry in South Carolina and worldwide. Although harmless to humans, infections by viruses frequently cause high mortalities and near total loss of farmed shrimp crops. Lightner \& Redman (1998) list over 20 viruses recognized for penaeid shrimp worldwide. The major viruses of concern relative to native stocks in the South Atlantic Bight (USA) are: taura syndrome virus (TSV), white spot syndrome virus (WSSV), yellow head virus (YHV), and the infectious hypodermal and hematopoietic necrosis virus (IHHNV). Shrimp virus infections have reduced the US farmed shrimp production by ca. $50 \%$ in recent years (Rosenberry 1996). Since 1994, global production of farmed shrimp decreased from $733000 \mathrm{mt}$ in 1994 to an estimated $660000 \mathrm{mt}$ in 1997 (Rosenberry 1997). A large part of this decline can be traced to shrimp virus problems. It is estimated that in 2001, WSSV caused losses of $300000 \mathrm{mt}$ of shrimp, worth more than 1 billion US dollars (Rosenberry 2001).

Until recently, in the USA, South Carolina farmed shrimp production has been second only to that of Texas, and in 1995 the industry consisted of 18 farms, producing over $500 \mathrm{mt}$ of shrimp. The appearance of IHHNV in the late 1980s prompted a Sea Grant sponsored workshop on introductions and transfers of marine organisms (Devoe 1992). This effort resulted in the strengthening of regulations designed to better control importation and to prevent escapement of nonindigenous species from aquaculture facilities. In 1996, the appearance of a new serious non-indigenous pathogen, TSV, at shrimp culture facilities caused catastrophic damage to crops (USMSFP 1996). Available evidence suggests that TSV was imported with infected postlarvae. This infected seed stock was 
shipped to South Carolina from a previously certified SPF (specific pathogen free) producer that had become contaminated. Since 1996, South Carolina has not had any further TSV epizootic events. In January of 1997, WSSV was identified at culture facilities in South Carolina.

WSSV was first reported from Northeast Asia in 1992 and spread throughout the region during the 1990s causing devastating declines in farmed shrimp production (Flegel 1997). WSSV was identified in captive shrimp in South Carolina in 1997, and the available evidence suggested the infections were derived from the wild (Browdy \& Holland 1998). WSSV is unique among shrimp viruses in that it infects a variety of crustaceans. WSSV-like genetic material has been found in samples from white shrimp, grass shrimp, fiddler crabs, blue crabs, and stone crabs in South Carolina (R.W.C. unpubl. data). These crustaceans potentially serve as reservoirs for WSSV, with the possibility of re-infecting wild as well as farmed shrimp populations. Archived DNA samples suggest a WSSVlike virus may have existed in the southeastern USA as early as 1988 (R.W.C. unpubl. data). At present, there are not sufficient data to determine whether the WSSV infections identified in captive white shrimp in South Carolina resulted from a recent introduction from Asia or from indigenous carriers.

Risks of shrimp virus introduction are not limited to transfer of live animals for shrimp culture. Two other potentially important sources of shrimp viruses are carrier organisms in ship ballast water and frozen seafood products. Invasions of a wide range of nuisance organisms, including a number of crustaceans, have been linked to the release of ballast water (Carlton 1992). In many countries, farmed shrimp are harvested during the acute phase of virus outbreaks to salvage part of the crop and minimize losses. The infected shrimp are frozen and sold in the USA for consumption or for use as fishing bait. Viable virus particles have been found in bait shrimp (Prior et al. 2001) and in frozen commodity shrimp in the USA (Durand et al. 2000). If introduced into local waters as bait or processing waste, these tissues could represent a vector for infection of indigenous crustaceans.

Appearance of new shrimp viruses in South Carolina has increased concerns over the threat that imported pathogens pose to native species. A recent report (Chang et al. 2001) demonstrated the presence of WSSV in blue crabs Callinectes sapidus in coastal US waters, but there was no indication that the species suffered from the disease. More attention is being paid to factors related to the health of marine organisms in our coastal ecosystems, but little is known about the disease status of the commercially significant native shrimp stocks in the South Atlantic Bight. The present study was designed to assess the presence of WSSV in stocks of commercially significant penaeid species in this region. WSSV was selected for study as it is a DNA virus for which several PCR primer sets have been developed (Lightner 1996, Lo et al. 1996, Takahashi et al. 1996, Nunan \& Lightner 1997). In addition, we examine the histopathology of infected individuals and the potential for these infections to be passed to populations of the cultured species (Litopenaeus vannamei).

\section{MATERIALS AND METHODS}

Field collections. Three species of commercially important penaeid shrimp, Litopenaeus setiferus, Farfantepenaeus aztecus and F. duorarum, were collected by trawl tows taken by the Southeast Area Monitoring and Assessment Program (SEAMAP) from the coastal zone of the South Atlantic Bight between Cape Hatteras, North Carolina, and Cape Canaveral, Florida. Samples were collected during summer and fall 1999 (12 Jul to 24 Aug and 5 Oct to 8 Nov, respectively). Samples of the first 2 individuals of each species found from each trawl were collected, providing a random sub-sample of the population while assuring maximum tissue freshness. Subsequently, while evaluating the catch for species abundance, any suspect individuals observed with gross signs of disease were sampled separately. Gill tissue was preserved in sarcosyl-urea (1\% sarcosyl, $8 \mathrm{M}$ urea, $20 \mathrm{mM}$ sodium phosphate, 1 mM EDTA, pH 6.8) for DNA analysis. Additional gill material was frozen at $-80^{\circ} \mathrm{C}$ (without preservative) for subsequent use in bioassays. The remaining cephalothorax was placed in Davidson's preservative for subsequent histological examination.

Laboratory analyses. DNA was extracted from the preserved tissue following the methods of Chapman et al. (1999). This isolation protocol has been used in our previous studies of WSSV. Samples were screened with primer pairs 143F/145R described by Lo et al. (1996). This primer set amplifies shrimp DNA and serves to verify that the sample does not contain contaminants that prohibit DNA amplification. Tests for the presence of WSSV in the samples were conducted using 3 primer sets developed by Lo et al. (1996), Kimura et al. (1996) and Wang \& Lightner (NCBI accession number AF178573). Reaction conditions for the treatments using the viral primers was a $25 \mu \mathrm{l}$ reaction containing $2 \mu \mathrm{l}$ of template DNA, $1 \times$ buffer, $1.5 \mathrm{mM} \mathrm{MgCl}_{2}, 0.2 \mathrm{mM}$ of each dNTP, $0.5 \mu \mathrm{M}$ of each primer (Biosynthesis) and $2.5 \mathrm{U}$ of Taq DNA polymerase. The cycling parameters used were an initial cycle of $94^{\circ} \mathrm{C}$ for $4 \mathrm{~min}, 52^{\circ} \mathrm{C}$ for $45 \mathrm{~s}$ and $72^{\circ} \mathrm{C}$ for $3 \mathrm{~min}$. This was followed by 34 cycles of 94,52 and 
$72^{\circ} \mathrm{C}$ at $45 \mathrm{~s}$ each, respectively; and an extension at $72^{\circ} \mathrm{C}$ for $30 \mathrm{~min}$. The optimal conditions for each primer were determined in a previous experiment. All PCR reactions were set up in individually capped tube stripes and negative control reactions were set up every 8th tube. The amplification products were separated in a $1.5 \%$ agarose gel stained with ethidium bromide. Samples were scored as weakly positive if one or more of the amplification tests produced a weak band. The sample was considered as strongly positive if all 3 amplifications produced intense bands. The amplifications were repeated on samples testing positive for WSSV by PCR to reduce the possibility of false positives. All samples scored as positive were also screened by in situ hybridization and histological methods (available at www.diagxotics.com/insituout ofproc.html, Lightner \& Redman 1998). The later tests were conducted by Dr. Pam Parnell at the Clemson Veterinary Diagnostic Center in Columbia, South Carolina.

Homogenates of tissue samples testing positive for WSSV via PCR were used to test for infectivity in a susceptible line (Oceanic Institute Kona strain) of Litopenaeus vannamei. The homogenates were prepared from the gill tissue following the methods established in previous work (Prior et al. 2003). Before initialization of bioassay trials, pleopods from Kona sentinels (GH TK 3) were sampled in groups of 5, and the shrimp were stocked in groups of 20 in twelve $6 \mathrm{ft}(1.8 \mathrm{~m})$ tanks. The shrimp were held for $7 \mathrm{~d}$, during which time the pleopods were tested for WSSV via PCR. These tests were conducted to ensure that the shrimp were not infected with WSSV, at least to the detection limits of PCR. Groups that tested negative for WSSV were used in subsequent challenges. The WSSV-negative shrimp were placed in individual containers and held at $27^{\circ} \mathrm{C}$. The shrimp were challenged via injection (Prior et al. 2003) with homogenates prepared from gill tissues from each of the $32 \mathrm{~L}$. setiferus and Farfantepenaeus aztecus that tested positive for WSSV. Eight homogenates were also prepared from WSSVnegative shrimp taken during the field survey to serve as negative controls. Six L. vannamei individuals were used for each positive and negative test. In addition, a positive control was prepared from a specimen of $L$. vannamei previously diagnosed as WSSV infected. An additional negative control was prepared from $L$. vannamei (Oceanic Institute Kona strain) specimens that were clinically free of disease. Moribund shrimp were collected on a daily basis and the experiment was terminated after $10 \mathrm{~d}$ when the remaining individuals were sacrificed. Challenged and control shrimp were then tested for the presence of WSSV via PCR, histological examination and in situ hybridization.

Data analysis. For the purpose of this study, 2 basic types of analysis were conducted. The first was a comparison of the number of infected shrimp noted in each species and between seasons. Tests for homogeneity among species or between seasons were conducted by chi-square contingency tests with 1 degree of freedom. For the species comparisons, Farfantepenaeus aztecus and $F$. dourarum data were combined and contrasted to Litopenaeus setiferus. The second type of analysis was to compare the diagnostic procedures employed in this study as indicators of the disease status of individuals. To this end, we used the bioassay results as the gold standard as these data are clear and unambiguous in determining the ability of samples to communicate the disease to other organisms (cf. Pfeiffer 2002). For reasons that will be discussed below, we report only the sensitivity, specificity, positive (PPV) and negative (NPV) predictive values of the PCR, histological examination and in situ hybridization (IHC) relative to the bioassay and not other epidemiological measures concerning prevalence.

\section{RESULTS}

A total of 1150 specimens taken from the wild (586 Litopenaeus setiferus, 477 Farfantepenaeus aztecus and 87 F. dourarum) were examined during this study (Table 1). A complete listing of each individual and the results of the PCR tests are available from the corresponding author on request. Of the total number screened, 1130 individuals provided adequate DNA for WSSV testing and, of these, 32 individuals were considered positive $(2.8 \%)$. Most of the positive shrimp were L. setiferus (88\%) and all of the remaining positive individuals were F. aztecus (Table 2). A chi-square

Table 1. Screening and incidence of PCR-positive reactions for white spot syndrome virus in shrimp Litopenaeus setiferus, Farfantepenaeus aztecus and Farfantepenaeus duorarum collected during summer and fall along the South Atlantic Bight coast of the USA

\begin{tabular}{|c|c|c|c|c|c|c|c|c|c|}
\hline \multirow{2}{*}{$\begin{array}{l}\text { Sampling } \\
\text { season }\end{array}$} & \multicolumn{3}{|c|}{ No. of shrimp screened per species } & \multirow{2}{*}{$\begin{array}{c}\text { Total no. of } \\
\text { shrimp screened }\end{array}$} & \multicolumn{4}{|c|}{ No. positive for each primer set } & \multirow{2}{*}{$\begin{array}{l}\text { No. positive } \\
\text { shrimp }\end{array}$} \\
\hline & L. setiferus & F. aztecus & F. duorarum & & 143F-145R & $146 \mathrm{~F} 1 / \mathrm{R} 1$ & MIWA P1-P2 & WSSV \#9-8 & \\
\hline Summer 1999 & 316 & 253 & 23 & 592 & 582 & 2 & 0 & 15 & 17 \\
\hline Fall 1999 & 270 & 224 & 64 & 558 & 548 & 2 & 2 & 14 & 15 \\
\hline Totals & 586 & 477 & 87 & 1150 & 1130 & 4 & 2 & 29 & 32 \\
\hline
\end{tabular}


Table 2. Summary of incidence of PCR-positive reactions for white spot syndrome virus in shrimp Litopenaeus setiferus, Farfantepenaeus aztecus and Farfantepenaeus duorarum collected during summer and fall along the South Atlantic Bight coast of the USA

\begin{tabular}{|c|c|c|c|c|}
\hline \multirow{2}{*}{ Species } & \multicolumn{2}{|c|}{ Total sampled } & \multicolumn{2}{|c|}{ Observed positives } \\
\hline & No. & $\%$ of total & No. & $\%$ of total \\
\hline L. setiferus & 586 & 50.9 & 28 & 87.5 \\
\hline F. aztecus & 477 & 41.5 & 4 & 12.5 \\
\hline F. duorarum & 87 & 7.6 & 0 & 0.0 \\
\hline Total & 1150 & & 32 & \\
\hline
\end{tabular}

test showed significant differences in the percentage of infection between $L$. setiferus and F. aztecus. Of the 32 positive individuals, only 2 produced strong amplification products for all $3 \mathrm{WSSV}$ primer sets. The PCR product of the 9/8 primer set (Wang and Lightner; NCBI accession number AF178573) amplification from one of the strong positives was sequenced (Medical University of South Carolina DNA sequencing core). The results exactly matched the sequence in GenBank and verified the presence of WSSV DNA.

Histological examination of the PCR positive individuals (Table 3) failed to find evidence of WSSV

Table 3. Results of diagnostic testing for suspect and randomly selected control shrimp Litopenaeus setiferus, Farfantepenaeus aztecus and Farfantepenaeus duorarum collected during summer and fall along the South Atlantic Bight coast of the USA. H\&E: Hematoxlyn \& Eosin histology for tissue damage; IHC: in situ hybridization test

\begin{tabular}{|c|c|c|c|c|c|c|c|c|}
\hline \multirow[t]{3}{*}{ Species } & \multicolumn{3}{|c|}{ _Analysis of field specimens } & \multicolumn{5}{|c|}{ Infectivity tests } \\
\hline & PCR & $\mathrm{H} \& \mathrm{E}$ & $\mathrm{IHC}$ & $\mathrm{n}$ & $\%$ mortality & PCR & $H \& E$ & $\mathrm{IHC}$ \\
\hline & result & result & result & & & (no. of $\mathrm{p}$ & tives/r & ested) \\
\hline \multicolumn{9}{|l|}{ Summer 1999} \\
\hline (Negative control) & - & - & - & 10 & 0 & $0 / 5$ & $0 / 2$ & $0 / 2$ \\
\hline (Positive control) & - & - & - & 10 & 100 & $10 / 10$ & $4 / 4$ & $4 / 4$ \\
\hline L. setiferus & Negative & Negative & Negative & 6 & 0 & $0 / 3$ & $0 / 2$ & $0 / 2$ \\
\hline F. aztecus & Negative & Negative & Negative & 6 & 0 & $0 / 5$ & $0 / 2$ & $0 / 2$ \\
\hline F. aztecus & Negative & Negative & Negative & 6 & 0 & $0 / 6$ & $0 / 2$ & $0 / 2$ \\
\hline L. setiferus & Negative & Negative & Negative & 6 & 0 & $0 / 6$ & $0 / 2$ & $0 / 2$ \\
\hline L. setiferus & Negative & Negative & Negative & 6 & 0 & $0 / 4$ & $0 / 2$ & $0 / 2$ \\
\hline F. aztecus & Negative & Negative & Negative & 6 & 33 & $1 / 6$ & $0 / 3$ & $0 / 3$ \\
\hline L. setiferus & Negative & Negative & Negative & 6 & 0 & $0 / 6$ & $0 / 2$ & $0 / 2$ \\
\hline L. setiferus & Negative & Negative & Negative & 6 & 17 & $0 / 5$ & $0 / 2$ & $0 / 2$ \\
\hline L. setiferus & WSV+ & Negative & Negative & 5 & 0 & $0 / 5$ & $0 / 2$ & $0 / 2$ \\
\hline L. setiferus & WSV+ & Negative & Negative & 5 & 0 & $0 / 4$ & $0 / 2$ & $0 / 2$ \\
\hline L. setiferus & WSV+ & Negative & Negative & 5 & 0 & $0 / 5$ & $0 / 2$ & $0 / 2$ \\
\hline L. setiferus & WSV+ & Negative & Negative & 5 & 0 & $0 / 5$ & $0 / 2$ & $0 / 2$ \\
\hline L. setiferus & WSV+ & Negative & Negative & 5 & 0 & $0 / 5$ & $0 / 2$ & $0 / 2$ \\
\hline L. setiferus & WSV+ & Negative & Negative & 5 & 0 & $0 / 5$ & $0 / 2$ & $0 / 2$ \\
\hline F. aztecus & WSV+ & Negative & Negative & 6 & 0 & $0 / 6$ & $0 / 2$ & $0 / 2$ \\
\hline L. setiferus & WSV+ & Negative & Negative & 6 & 0 & $0 / 5$ & $0 / 2$ & $0 / 2$ \\
\hline L. setiferus & WSV+ & Negative & Negative & 5 & 20 & $0 / 5$ & $0 / 3$ & $0 / 3$ \\
\hline L. setiferus & WSV+ & Negative & Negative & 6 & 0 & $1 / 6$ & $0 / 2$ & $0 / 2$ \\
\hline L. setiferus & WSV+ & Negative & Negative & 5 & 0 & $1 / 5$ & $0 / 2$ & $0 / 2$ \\
\hline F. aztecus & WSV+ & Negative & Negative & 6 & 0 & $1 / 6$ & $0 / 2$ & $0 / 2$ \\
\hline L. setiferus & WSV+ & Negative & Negative & 5 & 0 & $0 / 5$ & $0 / 2$ & $0 / 2$ \\
\hline L. setiferus & WSV+ & Negative & Negative & 5 & 0 & $0 / 5$ & $0 / 2$ & $0 / 2$ \\
\hline L. setiferus & WSV+ & Negative & Negative & 6 & 0 & $0 / 6$ & $0 / 2$ & $0 / 2$ \\
\hline L. setiferus & WSV+ & Negative & Negative & 6 & 0 & $0 / 6$ & $0 / 2$ & $0 / 2$ \\
\hline F. aztecus & WSV+ & Negative & Negative & 6 & 0 & $0 / 5$ & $0 / 2$ & $0 / 2$ \\
\hline \multicolumn{9}{|l|}{ Fall 1999} \\
\hline (Negative control) & - & - & - & 6 & 0 & $0 / 6$ & $0 / 6$ & $0 / 6$ \\
\hline (Positive control) & - & - & - & 6 & 100 & $6 / 6$ & $1 / 1$ & $1 / 1$ \\
\hline L. setiferus & WSV++ & WSV+ & WSV+ & 6 & 100 & $6 / 6$ & $3 / 3$ & $3 / 3$ \\
\hline L. setiferus & WSV+ & Negative & Negative & 6 & 0 & $0 / 2$ & $0 / 2$ & $0 / 2$ \\
\hline L. setiferus & WSV+ & Negative & Negative & 6 & 0 & $0 / 2$ & $0 / 2$ & $0 / 2$ \\
\hline L. setiferus & WSV+ & Negative & Negative & 6 & 17 & $0 / 3$ & $0 / 5$ & $0 / 5$ \\
\hline L. setiferus & WSV+ & Negative & Negative & 6 & 17 & $0 / 6$ & $0 / 5$ & $0 / 5$ \\
\hline L. setiferus & WSV+ & Negative & Negative & 6 & 0 & $0 / 2$ & $0 / 2$ & $0 / 2$ \\
\hline L. setiferus & WSV+ & Negative & Negative & 6 & 0 & $0 / 2$ & $0 / 2$ & $0 / 2$ \\
\hline L. setiferus & WSV+ & Negative & Negative & 6 & 0 & $0 / 2$ & $0 / 2$ & $0 / 2$ \\
\hline L. setiferus & WSV+ & Negative & Negative & 6 & 0 & $0 / 2$ & $0 / 2$ & $0 / 2$ \\
\hline L. setiferus & WSV+ & Negative & Negative & 6 & 0 & $0 / 2$ & $0 / 2$ & $0 / 2$ \\
\hline F. aztecus & WSV+ & Negative & Negative & 6 & 67 & $1 / 5$ & $0 / 2$ & $0 / 2$ \\
\hline L. setiferus & WSV+ & Negative & Negative & 6 & 17 & $1 / 6$ & $0 / 5$ & $0 / 5$ \\
\hline L. setiferus & WSV+ & Negative & Negative & 6 & 17 & $1 / 6$ & $0 / 5$ & $0 / 5$ \\
\hline L. setiferus & WSV+ & Negative & Negative & 6 & 33 & $1 / 6$ & $1 / 5$ & $1 / 5$ \\
\hline L. setiferus & WSV++ & Negative & Negative & 6 & 67 & $4 / 6$ & $2 / 4$ & $2 / 4$ \\
\hline
\end{tabular}


infection in any of the weakly positive samples. These individuals were also negative by in situ hybridization (IHC). Only one of the strong positives showed evidence of WSSV infection by histology and IHC (Table 3), and this individual showed significant severe tissue damage. The bioassay tests for infectivity of the PCR-positive individuals (Table 3) showed that the weakly positive individuals caused limited mortality in test shrimp. Both of the strong positive individuals and one weakly positive individual caused more than $60 \%$ mortalities in these tests. PCR analyses of the test shrimp after viral challenges (Table 3 ) found some evidence of WSSV virus in trials where mortality was low $(<33 \%)$. Histological examination and IHC of postchallenged individuals showed that those challenged with weakly positive material rarely showed any evidence of WSSV infection. These examinations were more likely to show WSSV infection when the test organisms were injected with strong positive material (Table 3).

A total of 17 positive individuals were collected during the summer and 15 during the fall of 1999 (Table 1). Both strong positive individuals were collected during the fall, but the number of positive individuals was not different between summer and fall (Chi-square test). Positive shrimps were taken from Georgia to Cape Lookout, North Carolina. Both of the strong positive individuals were taken in South Carolina waters.

Using the bioassay results as the gold standard, comparisons of the various tests for disease gave a sensitivity of 0.25 and specificity of 1.0 for the IHC and histological examination. The PCR-based tests gave a sensitivity of 1.0 and specificity of 0.2 . The IHC and histological examination gave positive predictive values (PPV) of 1.0 and negative predictive values (NPV) of 0.875 . The PCR tests gave PPVs of 0.875 and NPVs of 0.125 .

\section{DISCUSSION}

The present study is relevant to several issues concerning the presence of WSSV in wild populations, the ability of various detection methods to diagnose the presence of the virus and the future of aquaculture in the southeastern USA.

Previous studies in Asia demonstrated the presence of WSSV in a wide range of crustaceans including shrimp, crabs and lobsters (Chang et al. 1998, Wang et al. 1998). More recently, Chang et al. (2001) demonstrated the presence of WSSV in blue crabs along the coast of the USA. The later report is especially interesting as $27 \%$ of the individuals surveyed were positive for WSSV via 2-step PCR. These animals did not appear to be symptomatic and Chang et al. (2001) suggested that they were reservoir hosts for the virus. In this report, we extend the known hosts of WSSV in the wild to Litopenaeus setiferus and Farfantepenaeus aztecus. In addition, we have demonstrated that the virions are capable of inducing significant mortalities in a susceptible strain of $L$. vannamei.

Unlike the results of Chang et al. (2001), we were unable to detect the presence of WSSV by in situ hybridization or histological examination in weakly positive (and one strongly positive) individuals. We believe the discrepancy stems from several sources. First, Taq polymerase concentrations in our PCR reactions were 4 times that used by Chang et al. (2001). This increases the efficiency of the reaction, especially in later stages, when the enzyme loses catalytic efficiency (Gefland \& White 1990). Second, our photographic detection system is far more sensitive (ca. 100 times) than those commercially available, and nearly as sensitive as some immunohistochemcial methods (Chapman \& Brown 1989). Third, most of the weakly positive individuals were scored as positive due to a weakly fluorescing band in the PCR reaction using the 9/8 primer set. This primer set amplifies a 484 base fragment as compared to the $982 \mathrm{bp}$ fragment generated by P1/P2 (Kimura et al. 1996) and the 1447 bp fragment generated by $146 \mathrm{~F} 1 / \mathrm{R} 1$ (Lo et al. 1996). It is well known that smaller fragments are more efficiently amplified than larger ones (Innis \& Gefland 1990). All of these factors would tend to increase the likelihood of detecting WSSV in a single-step PCR. Chang et al. (2001 and references therein) have used a 2-step PCR approach to increase sensitivity. We have avoided the 2-step PCR as it has been most unreliable in our hands, generating many false positive reactions. Whether our methods are more or less sensitive than the 2-step approach remains to be investigated. However, the present data clearly show that we are able to detect WSSV at levels well below those required to induce significant mortalities in sensitive organisms.

Our results also indicate that PCR-based diagnostics are far more sensitive in detecting the presence of WSSV in shrimp than with histological examination or IHC. The estimates of sensitivity for the PCR-based diagnostic was 1.0 compared to the 0.25 for IHC or histological examination tests. These results are consistent with previous work (Durand \& Lightner 2002, Durand et al. 2003) where it has been shown that highly sensitive quantitative PCR methods can detect as few as 4 copies of WSSV. This is far below the level required to induce mortality in per os challenged shrimp (Durand \& Lightner 2002). The present data extends this conclusion, by demonstrating that relatively simple PCR methods can detect WSSV at levels well below those that cause mortality in $96 \mathrm{~h}$ bioassays, 
Whether these low-level infections will ultimately overwhelm the defense system of the host or become sufficiently high that they can be transmitted to other individuals is not known.

We have not provided estimates of the prevalence of WSSV in the wild shrimp populations based upon our data for several reasons. First, many of the animals that tested positive for WSSV were selected in the field because they manifested some symptoms of disease. Hence the samples used in the laboratory tests were biased in favor of an increased prevalence of disease and were not a random sample of the wild population. Further, the full range of diagnostics tests were run mainly on the PCR-positive individuals, with some negative individuals tested as controls. As such, our data are biased away from false negative results for the PCR-based diagnostic and the sensitivity of the test is likely overestimated, and specificity underestimated. We have chosen not to provide these estimates, as the prevalence of disease based upon these data could be misconstrued and cause undue alarm and serious economic consequences.

The SEAMAP trawls were conducted intensively over a large geographic region to provide fisheriesindependent data on the distribution and abundance of target species. When coupled with the random sampling design and additional collections aimed at suspect individuals, the present study provides some indications on relative abundance of infected individuals and on geographic distribution of infected individuals. It should be noted that there are no shrimp farms in North Carolina or Georgia; however, no outbreaks of WSSV were reported for aquaculture stocks in South Carolina in 1999. Large-scale processing of imported shrimp is limited to the far southern part of the geographic range sampled. Although WSSV-positive animals were most frequently encountered in South Carolina, this was the most exhaustively surveyed region. Due in part to the relatively low incidence of disease, data were insufficient to draw statistically relevant conclusions on the distribution of the disease over the geographic range sampled. No seasonal differences were observed in the frequency of positive animals from the survey region. This is particularly interesting considering the expected increase in expression of disease with decreasing water temperatures (Vidal et al. 2001). An important finding of the present study is the discovery of significant tissue damage related to WSSV infection in a wild-caught animal. Several studies have found evidence of WSSV in wild shrimp and crabs (cf. Lo et al. 1996, Chang et al. 2001, Nunan et al. 2001), but to our knowledge there has yet to be a report of significant tissue damage or other overt signs of disease. One of the wild Litopenaeus setiferus individuals found in this survey was not only strongly positive for WSSV, but also had a G-4 level of infection. This indicates that $L$. setiferus is not an asymptomatic carrier, but can be severely afflicted by the disease. This finding could have significant fishery management implications should a given population carrying the virus encounter a significant secondary stressor (such as drought or winter freeze). Whether this level of susceptibility extends to other shrimp species is not known. The statistical difference in rates of infection between L. setiferus and Farfantepenaeus aztecus could tend to suggest that some shrimp species may be less susceptible to this disease. This notion is supported by the observation that $F$. duororum did not suffer mortality above the controls during challenge with WSSV (Wang et al. 1999). However, a number of other factors could account for the differences in prevalence of infection observed and the scope of the present study precludes the drawing of conclusions on relative susceptibility. A number of studies have demonstrated that WSSV causes serious disease in many species of penaeid shrimp and in a variety of other decapod crustaceans that are known to be infected (Chang et al. 1998, Lightner et al. 1998, Wang et al. 1998, Lightner 1999, Wang et al. 1999, Chang et al. 2001). The fact that severe infections are rarely seen in the wild could be due to the limited sampling that has been conducted, vulnerability of diseased individuals to predation, the rarity of the event and swift progression of the disease. The present study suggests that white spot syndrome virus can cause serious disease in at least one species of shrimp in the wild.

Acknowledgements. The assistance of Mr. Pearse Webster and Ms. Jeannie Boylan in collecting specimens for this research is appreciated. This effort was supported by the Saltonstall-Kennedy program NMFS/NOAA grant number (NA97FD0066) and The SEAMAP program NOAA/NMFS grant number NA07FF0004. This paper is contribution number 02-02 to the Cooperative Institute of Fisheries Molecular Biology, \#3 to the Marine Genome Project and \#542 to the Marine Resources Division of the South Carolina Department of Natural Resources.

\section{LITERATURE CITED}

Browdy CL, Holland AF (1998) Shrimp virus risk management: a South Carolina case study. Aquat Nuisance Spec Digest 2:25-35

Carlton JT (1992) Marine species introductions by ships' ballast water: an overview. In: Devoe R (ed) Introductions and transfers of marine species: achieving a balance between economic development and resource protection. Proc Conf and Workshop, Hilton Head Island, South Carolina, October 30 to November 2, 1991. South Carolina Sea Grant Consortium, Charleston, p 23-26

Chang PS, Chen HC, Wang YC (1998) Detection of white spot syndrome associated baculovirus in experimentally infected wild shrimp, crab and lobsters by in situ hybridization. Aquaculture 164:233-242 
Chang YS, Peng SE, Wang HC, Hsu HC and 5 others (2001) Sequencing and amplified restriction fragment length polymorphism analysis of ribonucleotide reductase large subunit gene of the white spot syndrome virus in blue crab (Callinectes sapidus) from American coastal waters. Mar Biotechnol 3:163-171

Chapman RW, Brown BL (1989) Two methods to detect DNA fragments produced by restriction enzymes. Anal Biochem 177:199-202

Chapman RW, Sedberry GR, Koenig, CC, McGovern JC (1999) The genetic consequences of reproductive variance. Studies in species with different longevities. In: Musik JA (ed) Life in the slow lane: the ecology and conservation of long lived animals. American Fisheries Society, Bethesda, MD, p 169-180

Devoe R (1992) Introductions and transfers of marine species: achieving a balance between economic development and resource protection. Proc Conf and Workshop, Hilton Head Island, South Carolina, October 30 to November 2, 1991. South Carolina Sea Grant Consortium, Charleston

Durand SV, Lightner DV (2002) Quantitative real time PCR for the measurement of white spot syndrome virus in shrimp J Fish Dis 25:381-400

Durand SV, Tang KFJ, Lightner DV (2000) Frozen commodity shrimp: potential avenue for introduction of white spot syndrome virus and yellow head virus. J Aquat Anim Health 12:128-135

Durand SV, Redman RM, Mohney LL, Tang-Nelson K, Bonami JR, Lightner DV (2003) Qualitative and quantitative studies on the relative virus load of tails and heads of shrimp acutely infected with WSSV. Aquaculture 216: 9-18

Flegel TW (1997) Progress in the diagnosis and control of Yellow Head virus (YHV) and White Spot virus (WSSV). World Aquaculture 97' book of abstracts. World Aquaculture Society, Baton Rouge, LA. Abstracts, p 180

Gefland DH, White TJ (1990) Thermostable DNA polymerases. In: Innis MA, Gefland DH, Sninsky JJ, White TJ (eds) PCR protocols: a guide to methods and applications. Academic Press, New York, p 129-141

Innis MA, Gefland DH (1990) Optimization of PCRs. In: Innis MA, Gefland DH, Sninsky JJ, White TJ (eds) PCR protocols: a guide to methods and applications. Academic Press, New York, p 3-12

Kimura T, Yamano K, Nakano H, Momoyama K, Hiraoka M, Inouye K (1996) Detection of penaeid rod-shaped DNA virus (PRDV) by PCR. Fish Pathol 31:93-98

Lightner DV (1996) A handbook of shrimp pathology and diagnostic procedures for diseases of cultured penaeid shrimp. World Aquaculture Society, Baton Rouge, LA

Lightner DV (1999) The penaeid shrimp viruses TSV, IHHNV, WSSV, and YHV: current status in the Americas, available diagnostic methods and management strategies. J Appl Aquacult 9:27-52

Lightner DV, Redman RM (1998) Shrimp diseases and current diagnostic methods. Aquaculture 164:201-220

Editorial responsibility: Timothy Flegel,

Bangkok, Thailand
Lightner DV, Hasson KW, Redman RM, White BL (1998) Experimental infection of Western Hemisphere penaeid shrimp (Crustacea: Decapoda) with Asian isolates of white spot and yellow head syndrome viruses. J Aquat Anim Health 10:271-281

Lo CF, Ho CH, Peng SE, Chen CH and 7 others (1996) White spot syndrome baculovirus (WSBV) detected in cultured and captured shrimp, crabs and other arthropods. Dis Aquat Org 27:215-225

Nunan L, Lightner DV (1997) Development of a nonradioactive gene probe by $\mathrm{PCR}$ for detection of white spot syndrome virus (WSSV). J Virol Methods 63:193-201

Nunan LM, Arce SM, Staha RJ, Lightner DV (2001) Prevalence of Infectious Hypodermal and Hematopoietic Necrosis Virus (IHHNV) and White Spot Syndrome Virus (WSSV) in Litopenaeus vannamei in the Pacific Ocean off the Coast of Panama. J World Aquacult Soc 32:330-334

Pfeiffer DU (2002) Veterinary epidemiology — an introduction. Royal Veterinary College, University of London

Prior S, Segars A, Browdy CL (2001) A preliminary assessment of live and frozen bait shrimp as indicators and/or vectors for shrimp viruses. In: Aquaculture 2001 book of abstracts. World Aquaculture Society, Baton Rouge, LA, p 541

Prior S, Browdy CL, Sheppard EF, Laramore R, Parnell P (2003) Controlled bioassay systems for determination of lethal infective doses of tissue homogenates containing taura syndrome or white spot syndrome viruses. Dis Aquat Org 54:89-96

Rosenberry B (1996) World shrimp farming 1996. Shrimp News International, San Diego

Rosenberry B (1997) World shrimp farming 1997. Shrimp News International, San Diego

Rosenberry B (2001) World shrimp farming 2001. Shrimp News International, San Diego

Takahashi Y, Itami, T, Maeda M, Suzuki N and 9 others (1996) Polymerase chain reaction (PCR) amplification of bacilliform virus (RV-PJ) DNA in Penaeus japonicus (Bate) and systemic ectodermal and mesodermal baculovirus (SEMBV) DNA in Penaeus monodon (Fabricius). J Fish Dis 19 (5):399-403

USMSFP (1996) The FY96 Annual Report of the US Marine Shrimp Farming Program, Vol. 1. Oceanic Institute, Honolulu

Vidal OM, Granja CB, Aranguren F, Brock JM, Salazar M (2001) A profound effect hyperthermia on the survival of Litopenaeus vannamei juveniles infected with White Spot Syndrome Virus. J World Aquacult Soc 32:364-372

Wang Q, White BL, Redman RM, Lightner DV (1999) Per os challenge of Litopenaeus vannamei postlarvae and Farfantepenaeus duorarum juveniles with six geographic isolates of white spot syndrome virus. Aquaculture 170: 179-194

Wang YC, Lo CF, Chang PS, Kou GH (1998) Experimental infection of white spot baculovirus in some cultured and wild decapods in Taiwan. Aquaculture 164:221-231

Submitted: October 8, 2003; Accepted: February 3, 2004

Proofs received from author(s): May 19, 2004 